\title{
Familial Monosomy 7 Syndrome Associated with Myelodysplasia
}

\author{
Surbhi Rathi ${ }^{1}$ (D) Santosh Kondekar ${ }^{1} \cdot$ Purvi Kadakia $^{2} \cdot$ Swapna Sawardekar $^{3} \cdot$ Tapobrata De $^{1}$
}

Received: 15 March 2019 / Accepted: 16 May 2019 / Published online: 17 June 2019

(C) Dr. K C Chaudhuri Foundation 2019

To the Editor: Familial monosomy is defined as bone marrow monosomy 7 occurring as the sole anomaly affecting $>2$ siblings and has been reported in fourteen families [1,2].

We present here, a case of myelodysplastic syndrome (MDS), associated with familial monosomy 7 in an 8-y-old male child. To our knowledge, this is the fifteenth family reported with monosomy 7 .

The child presented with history of repeated episodes of petechial rash, bleeding gums, and fever, with frequent platelet transfusions since the age of $4 \mathrm{y}$. Bone marrow aspiration (BMA) performed 2 mo before was normal. He was diagnosed with chronic immune thrombocytopenic purpura. His elder sister had succumbed to acute myeloid leukemia (AML) at the age of $8 \mathrm{y}$; she had associated monosomy 7 in $70 \%$ of her bone marrow cells.

On examination, pallor, petechiae and ecchymoses (largest, up to $6 \mathrm{~cm}$ ) on the trunk, abdomen, and lower limbs were seen. Firm splenomegaly ( $4 \mathrm{~cm}$ along its long axis) was noted.

Patient had hemoglobin level, $10.9 \mathrm{~g} / \mathrm{dl}$, total leucocyte count, 3400 cells $/ \mathrm{mm}^{3}$, absolute neutrophil count, 2300 cells $/ \mathrm{mm}^{3}$, and platelet count, $50,000 / \mathrm{mm}^{3}$. There were no blasts. BMA showed micronormoblastic and megaloblastic dyserythropoesis and diffuse fibrosis with reticulin (Grades 2 and 3). Immunohistochemistry showed marked reduction

Surbhi Rathi

supopu@gmail.com

1 Department of Pediatrics, Topiwala National Medical College and BYL Nair Charitable Hospital, A L Nair Road, Mumbai Central, Mumbai, Maharashtra 400 008, India

2 Department of Oncology, Topiwala National Medical College and BYL Nair Charitable Hospital, A L Nair Road, Mumbai Central, Mumbai, Maharashtra, India

3 Department of Pharmacology, Topiwala National Medical College and BYL Nair Charitable Hospital, A L Nair Road, Mumbai Central, Mumbai, Maharashtra, India in granulocyte series and small dysplastic megakaryocytes. Cytogenetics by fluorescent in-situ hybridization (FISH) revealed monosomy 7 in multiple clones in $90 \%$ of bone marrow cells. There was no evidence of monosomy 5 or monosomy 8 . Fetal hemoglobin levels were normal. He was diagnosed with MDS.

In view of non malignant marrow, prophylactic chemotherapy for AML was withheld. Patient's parents were offered genetic counseling and informed about poor prognosis. Allogenic hematopoietic stem cell transplantation was advised, however they could not afford the therapy.

Patient's 4-y-old male sibling, currently asymptomatic, was also investigated. BMA showed occasional dysplastic megakaryocytes without monosomy 7 . Bone marrow dysplasia is one of the early indicators of MDS and AML. A normal karyotype does not exclude future occurrence of mosaic monosomy 7 in peripheral blood and/or bone marrow [2]. We therefore considered this to be a case of familial monosomy 7 .

Both, the patient and his sibling, were advised to follow-up for detection of progression to AML.

\section{Compliance with Ethical Standards}

Conflict of Interest None.

\section{References}

1. Inaba $\mathrm{T}$, Honda $\mathrm{H}$, Matsui $\mathrm{H}$. The enigma of monosomy 7. Blood. 2018;131:2891-8.

2. Morrissette JJD, Wertheim G, Olson T. Familial monosomy 7 syndrome. 2010 Jul 8 [updated 2016 Jan 21]. In: Adam MP, Ardinger HH, Pagon RA, Wallace SE, Bean LJH, Stephens K, Amemiya A, editors. GeneReviews ${ }^{\circledR}$ [Internet]. Seattle (WA): University of Washington, Seattle; 1993-2019. Available at: http://www.ncbi. nlm.nih.gov/books/NBK45015/

Publisher's Note Springer Nature remains neutral with regard to jurisdictional claims in published maps and institutional affiliations. 